\title{
大振幅オイルダンパーシステム の実大加力試験
}

\section{LOADING TEST FOR FULL-SCALE PROTOTYPE OF LARGE-AMPLITUDE OIL DAMPER SYSTEM}

$\begin{array}{ll}\text { 杉本浩一 }-* 1 & \text { 小槻祥江 }- \text { 米 } * 1 \\ \text { 半澤徹也 } & * 1\end{array}$ 磯田和彦 -2

キーワード :

オイルダンパー, 加力試験, 大振幅, 地震時挙動, 免震

Keywords:

Oil damper, Loading test, Large-amplitude, Seismic behavior, Seismic isolation system

\section{Koichi SUGIMOTO — $* 1$}

Tetsuya HANZAWA — $* 1$

A large-amplitude oil damper system with twice the stroke and velocity of a normal oil damper has been developed. The damper system consists normal oil dampers connected in series. In order to make the displacement of dampers in the system same, "displacement adjustment mechanism" is connected in parallel. The mechanism consists of righthand threads and left-hand threads with same pitch. We made a fullscale prototype of the system and conducted loading tests. As a result, it is confirmed that the displacements of each damper are same, and the stroke and velocity are twice that of a normal oil damper.

\section{1.はじめに}

発生が予測されている南海トラフ地震などの巨大地震は、長周期 成分が卓越し継続時間の長い地震動を発生させ、超高層建物等の長 周期構造物の応答を増大させる危険性が指摘されている 1 ),2)。これら の地震動によって、免震建物の応答変位や応答速度は増大寸る傾向 にあり、免震建物に対し擁壁衝突時の衝撃緩衝装置やフェールセー フ、免震層変位の抑制などの対策案が検討されている例えば 3),4)。免震 層の応答変位を小さくするためには、ダンパー量を増すことが効果 的であるが、熊本地震の西原村で観測された地震動に対しては、一般 的なクリアランス内に免震層変位を収めることは困難であり、さら に免震層の応答速度が $150 \mathrm{~cm} / \mathrm{s}$ を超える可能性も示唆されている。 $1 \mathrm{~m}$ を超える変形や $150 \mathrm{~cm} / \mathrm{s}$ を超える速度は、既製のオイルダンパ 一の適用限界を超過し、既製のオイルダンパーでは対応することが できない。免震用オイルダンパーの許容最大速度を、より高速領域ま で対応可能とする研究はこれまでも行われている。最近では中山ら 5) が、原子力建屋用として、変位により減衰力を可変にして $250 \mathrm{~cm} / \mathrm{s}$ ま で対応可能なオイルダンパーの開発を行っている。また藤田ら ${ }^{6}$ は、 既製のオイルダンパーと同程度の形状のまま、許容最大速度を $270 \mathrm{~cm} / \mathrm{s}$ までとする免震用オイルダンパーの開発を行っている。こ れらのダンパーは新規の開発品であるため、免震建物への適用にあ たっては免震材料の認定を新たに取得する必要がある。また、許容最 大速度は大きいが、ストロークに関しては既製品と同等である。

そこで著者らは、既製の免震用オイルダンパーを用いて簡易な機 構によりストロークと許容最大速度を既製品オイルダンパーの 2 倍 に拡大する大振幅オイルダンパーシステムを開発した。本論文では、 2 章で開発した大振幅オイルダンパーシステムの概要について述心゙、 3 章では当該ダンパーシステムの成立性確認のために実施した実大 試験体を用いた水平 1 方向の大振幅、かつ高速度の動的加力試験に ついて報告する。4 章では当該ダンパーシステムが地震時の免震層の
水平 2 方向挙動に追従できることを確認するために実施した、水平 2 方向の動的加力試験について報告する。

\section{2. 大振幅オイルダンパーシステムの概要}

図 1 に示すように、既製の免震用オイルダンパーを直列に接続す れば、ストロークを 2 倍に拡大できる。しかし既製のオイルダンパ 一は、製造時における性能のばらつき (公差 $\pm 15 \%)$ が存在するため、 単純に直列接続しただけでは両オイルダンパーの変位に差が生じて しまい、地震による繰返しによってこれが累積し、2 倍のストローク が生じる前に片方のオイルダンパーがストロークエンドに達して損 傷する恐れがある。そこで、直列した両オイルダンパーの各変位を等 值とする変位調整機構(図 2)を考案した。変位調整機構は、リード(ね じ山のピッチ）が同じ右対じと左ねじのボールねじを組み合わせた 機構である。ボールねじは回転拘束されて軸方向移動のみを自在と し、㸚じが軸方向に変位すると各ボールねじに接合されたボールナ ットが回転する。さらに、各ボールナットの間をパイプにより連結す ることで、双方のボールナットの回転量が等しくなり、各ボールナッ トに対するボールねじの変位も一致する。図 3 に示すように、この 変位調整機構と直列したオイルダンパーを並列に配置し、両端と中 央部を相互に接続することにより、両オイルダンパーの変位を揃え ることが可能となり、大振幅、高速度に対応可能なオイルダンパーシ ステムを実現することができる。変位調整機構のねじ部には、両オイ ルダンパーの性能差（減衰力の差分）が軸力として生じる。ただし、

図 3 の構成のままではシステムの全体長さがオイルダンパー単体長 さの 2 倍と長大化する。建設現場での施工効率や運送等を考慮する と、全長はできるだけ短くしたい。そこで、オイルダンパーのシリン ダー部を軸方向に並べて配置することでシステム全体長さを短くす る。なお、シリンダー部を軸方向に並べて配置することで、オイルダ ンパーの軸心のずれによる、偶力モーメントが生じることとなる。
清水建設(侏技術研究所

（干 135-8530 東京都江東区越中島 3-4-17）

元清水建設侏技術研究所
Institute of Technology, Shimizu Corporation

*2 Former Institute of Technology, Shimizu Corporation 


\section{3. 実大試験体の水平 1 方向動的試験}

2 章に示す大振幅オイルダンパーシステムの成立性確認と性能検 証のため、水平 1 方向の大振幅・高速度の動的加力試験を実施した。 成立性としては、変位調整機構により直列に接続したオイルダンパ 一(以降、ダンパー) の変位が揃うこと、またシステムとして組み合 わせても、各ダンパー性能が単体での加力時と変化がないことを確 認した。性能検証としては、大振幅オイルダンパーシステムが大振 幅・高速度の加力時に想定する性能を発揮することを確認した。

\section{1 水平 1 方向試験体}

2 章で示した変位調整機構を用いた、大振幅オイルダンパーシステ ムの成立性を確認するため、水平 1 方向のみに可動する実大試験体 を製作した。図 4 の(a)、(b)に製作した大振幅オイルダンパーシステ ムの 1 方向試験体を示す。ダンパーのシリンダー部を軸方向に並心゙ て配置すると、軸心のずれによる偶力が生じるが、直列する 2 本の ダンパーを 2 対並列に接続する（ダンパー(1)、(2)及びダンパー(3)、

(4)）ことで、生じる偶力を打ち消寸構成とした(図 4(a))。全ダンパー の片端は鉄骨架台に接続させ、もう一方の端部は建物、もしくは固定 端に接続させる。鉄骨架台の下にはリニアガイドを設置し、水平 1 方 向のみ可動する試験体とした。また鉄骨架台中央は、ボールねじの軸 方向変位により回転する連結パイプと軸受を介して接続される。こ れにより、各ボールねじが D 変位すると、各ダンパーも D 変位し、 大振幅オイルダンパーシステムとしては $2 \mathrm{D}$ の変位が生じる(図 4(b)) 一方で、鉄骨架台の変位量はボールねじ 1 本分の変位 $\mathrm{D}$ となる。写 真 1 に 1 方向試験体を示す。ダンパー単体のストロークは $2600 \mathrm{~mm}$ 、 最大荷重は $1000 \mathrm{kN}$ 、許容最大速度は $150 \mathrm{~cm} / \mathrm{s}$ 、減衰性能は、 1 次減 衰係数 : $2500 \mathrm{kNs} / \mathrm{m} 、 2$ 次減衰係数 : $169.5 \mathrm{kNs} / \mathrm{m}$ のバイリニアであ る。ダンパー単体の取付長は $3340 \mathrm{~mm}$ であるが、大振幅オイルダン パーシステムの全長は $4500 \mathrm{~mm}$ であり、シリンダー部を並べて配置 することでダンパー2 本を単純に直列するよりも大幅に短くなって いる。図 5 に製作した試験体の減衰性能を示す。ダンパーを直列接 続するとストロークと最大速度が 2 倍となるが、減衰力は $1 / 2$ とな る。しかし、本大振幅オイルダンパーシステムは同じ直列ダンパーユ ニットをもう 1 対並列するため、全体の減衰力はダンパー2 本を並 列接続するのと同じになる。よって本試験体の許容最大速度は $300 \mathrm{~cm} / \mathrm{s}$ 、ストロークは $1200 \mathrm{~mm}$ 、最大荷重は $2000 \mathrm{kN}$ となる。

動的加力試験に先立ち、 1 方向試験体の鉄骨架台下部に使用してい るリニアガイドの摩擦力、摩擦係数を把握するための引張試験を実 施した。引張試験では、ダンパーは設置せずに鉄骨架台と変位調整機 構のみの状態で鉄骨架台にワイヤーを接続し、チェーンブロックを 用いて準静的に引張り、その時の引張荷重をばね科を用いて計測し た。鉄骨架台の重量は約 $2000 \mathrm{~kg}$ 、変位調整機構の重量は約 $800 \mathrm{~kg}$ の 合計約 $2800 \mathrm{~kg}$ である。引張荷重は $150 \mathrm{~N}$ であったため、リニアガイ ドの摩擦係数は約 0.005 であった。このリニアガイドの摩擦荷重は ダンパー荷重と比較して充分小さいため、本検討では無視した。

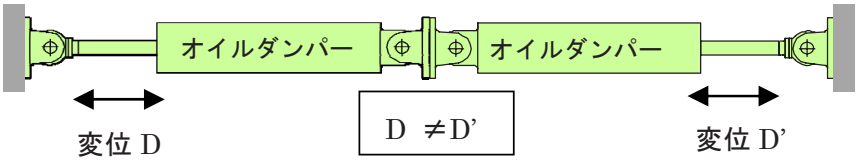

図 1 直列するオイルダンパー

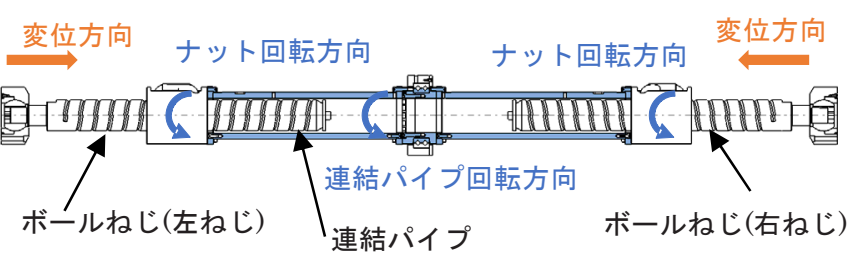

図 2 変位調整機構

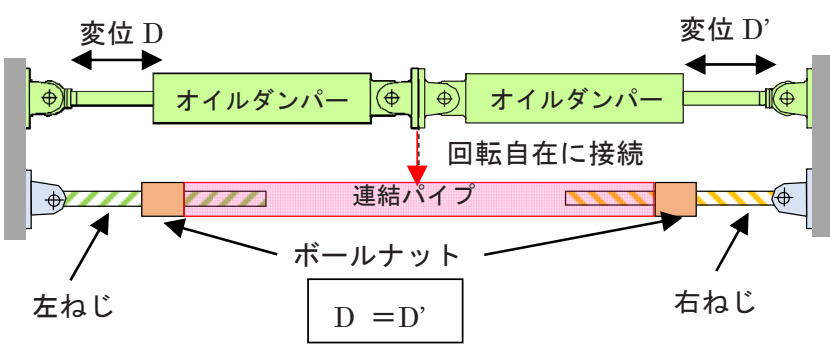

ねじ負担荷重：ダンパーの減衰力の差分荷重 図 3 変位調整機構を並列接続

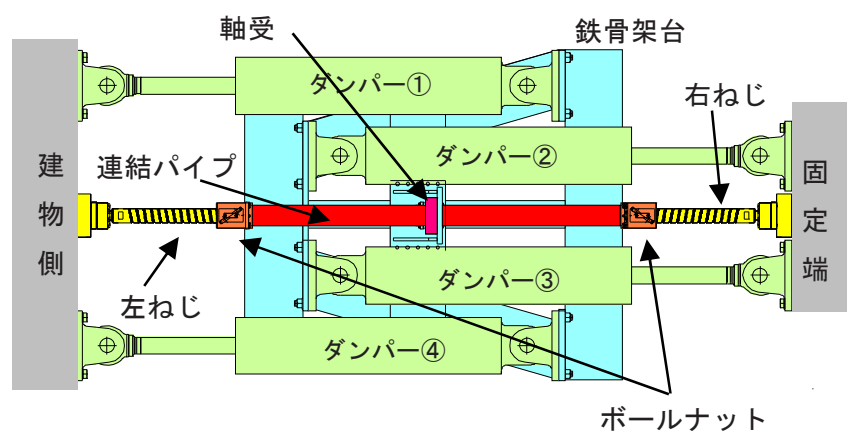

(a) 平面図

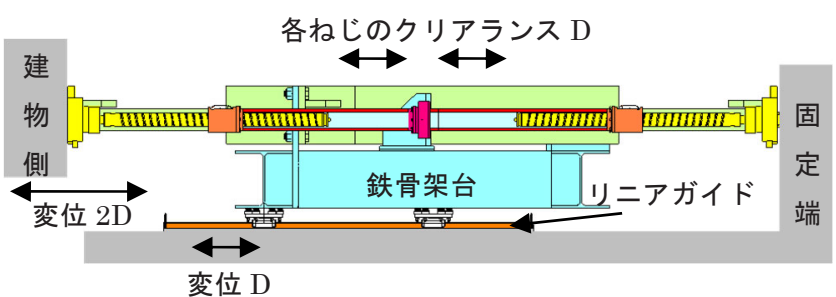

(b) 断面図

図 4 大振幅オイルダンパーシステムの 1 方向試験体

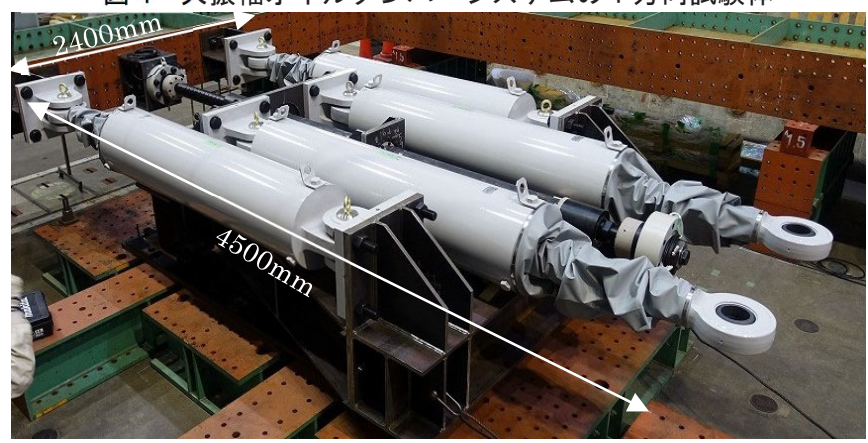

写真 1 実大 1 方向試験体

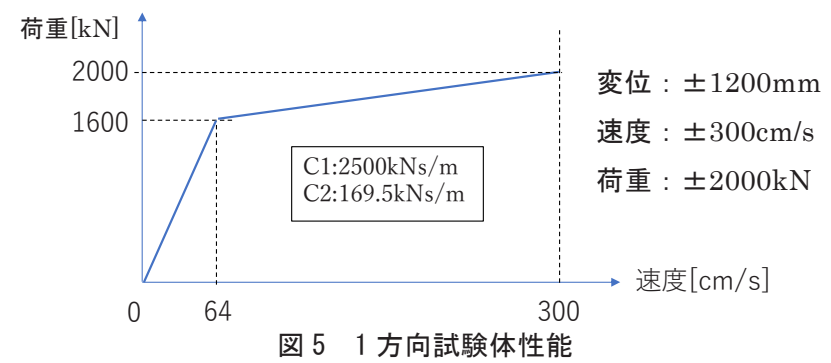




\section{2 水平 1 方向大振幅・高速度試験}

\section{2.1 試験機概要}

図 6 に、1 方向試験体の加力試験を実施した試験機とその仕様を 示す。試験体は図 5 に示す性能を有しているため、性能検証を行う ためには、加力振幅 $\pm 1200 \mathrm{~mm}$ 程度、加力速度 $100 \mathrm{~cm} / \mathrm{s}$ 以上、および 負担荷重 $2000 \mathrm{kN}$ 以上の試験機スペックが必要となる。そこで台湾 の NCREE ( National Center for Research on Earthquake Engineering）にある 2 軸（水平 1 軸と鉛直）試験機「BATS」を使 用して水平 1 方向動的加力試験を実施した。図 7 に 1 方向試験体設 置図を示す。試験機は、上部の反カフレームと水平 1 方向に可動す る振動台によって構成される。加力試験は、振動台と反力フレームに 各々治具を設置して 1 方向試験体の両端を接続し、振動台を動か寸 ことで加力を行った。図 4(b)で述べたように、振動台が 2D 変位した 場合、各ダンパーと鉄骨架台の変位はその $1 / 2$ の D となる。

\subsection{2 計測}

図 8 に試験体に設置した計測器の配置を示す。各ダンパーの変位 と荷重を測定するために、ダンパーのピストンロッド部にひずみゲ ージを貼り付け、シリンダー部にはダンパー変位を計測するレーザ 一変位計を設置した。なお、ピストンロッド部に貼り付けたひずみゲ ージによりダンパーの変位が制限されるため、 $800 \mathrm{~mm}$ を超える加力 振幅の場合はひずみゲージを外して加力を行った。また、変位調整機 構には、直列するダンパーの性能差から生じる減衰力の差分が軸力 として生じる。右礼じと左ねじの荷重をそれぞれ計測するため、ねじ の両端部にロードセルを設置した。1 方向試験体全体の変位と荷重は、 振動台に既設されている変位計と荷重計を用いて計測した。

\section{2.3 加力波}

図 9 に試験機の限界加力速度と本試験の加力範囲を示す。入力波 は正弦波とし、周期 3 秒 20 秒、振幅は最大 $\pm 1150 \mathrm{~mm}$ 、速度は最大 $\pm 115 \mathrm{~cm} / \mathrm{s}$ とし、加力周期に応じて振幅を調整して実施した。また、 正弦波の振幅は最大振幅となる部分を 3 波分（定常部）とし、始めと 終わりをそれぞれ 3 波ずつ漸増、漸減となるように作成した。

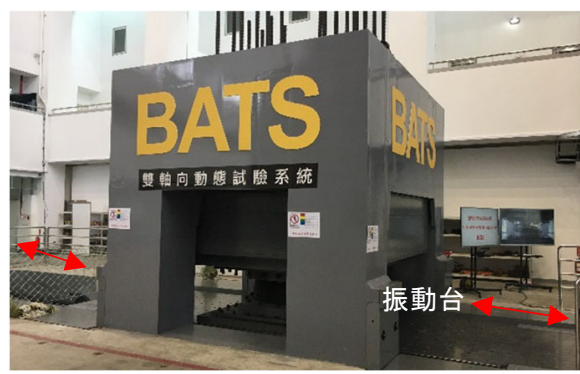

<試験機仕様>

振幅: $\pm 1,200 \mathrm{~mm}$

速度 : $\pm 150 \mathrm{~cm} / \mathrm{s}$

荷重：士4,000kN

図 6 水平 1 方向加力試験を実施した試験機 BATS（台湾 NCREE）

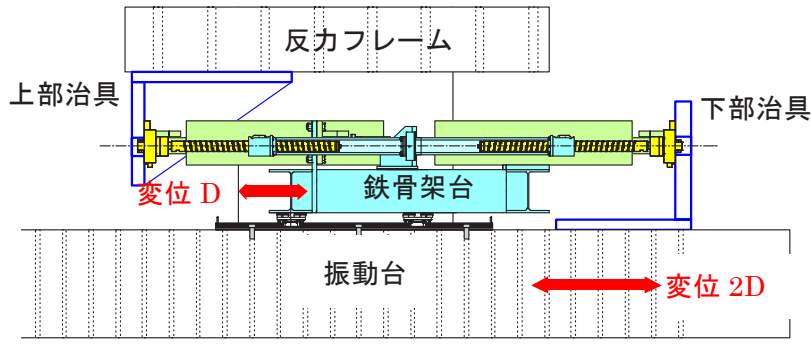

図 71 方向試験体設置図

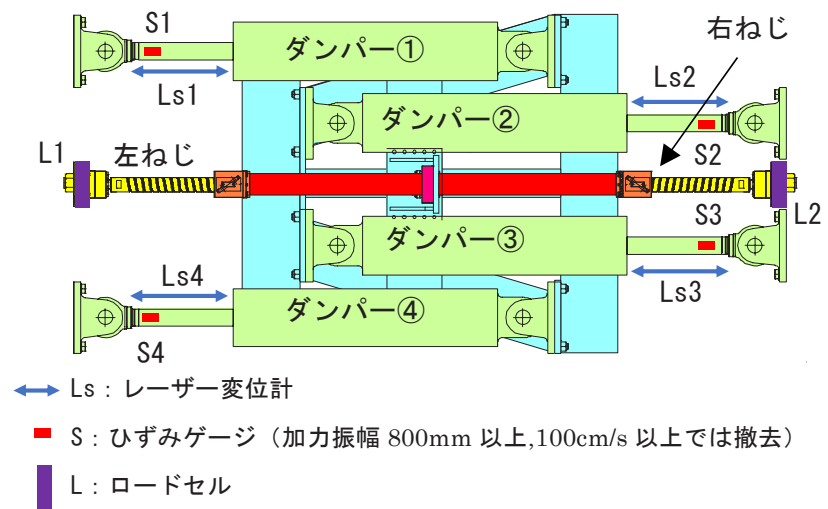

図 8 計測器設置位置

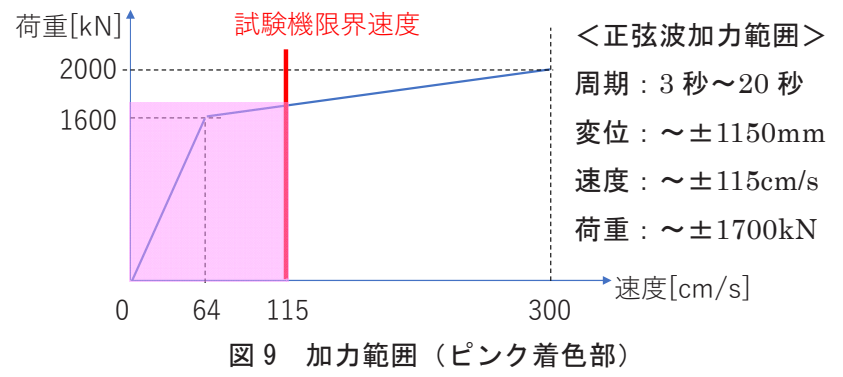

\section{3 試験結果}

図 10 に、ダンパー(1)の単体加力試験結果 (5 秒_加力振幅 $160 \mathrm{~mm}$ ) と大振幅オイルダンパーシステムの加力結果 (5 秒_加力振幅 $320 \mathrm{~mm}$ ) におけるダンパー(1)の荷重-変位関係を重ねて示す。なお、単体加力 試験は、出荷試験と同条件で製造工場にて実施した。図 10 より、シ ステムとして加力した場合においても、ダンパー11は単体で加力し た結果とほぼ同様の履歴ループが得られ、図 10 中に示寸荷重-変位 関係のループ面積から算出される減衰係数も概放一致している。使 用した 4 本のダンパーはどれも単体加力試験結果と、システムとし て加力した結果が概ね一致した。図 11(a)、(b)に、全加力試験におけ るダンパー(1)とダンパー(2)の最大荷重と最大速度の関係と、ダンパ 一(1)とダンパー(2)を単体で加力した際の最大荷重と最大速度の関係 も併せて示す。図 11(a)、(b)より、システム全体として加力した際の ダンパー単体の速度 - 荷重関係と、ダンパー単体を加力した際の速 度 - 荷重関係に差異がなく、大振幅オイルダンパーシステムには性 能のロスがないことが分かる。次に、図 12 (a) に振幅 $600 \mathrm{~mm}$ で加力 したケースの各ダンパーの変位時刻歴波形を示す。図 12(a)より、4 つのダンパー変位がほぼ一致していることが分かる。図 $12(\mathrm{~b})$ には変 位調整機構の右衿じと左㸚じの荷重差(図中オレンジ線)と、並列する ダンパーの荷重和（1＋（4)と（2)＋(3)）の差(図中グレー線)を重社描い ている。大振幅オイルダンパーシステムは、鉄骨架台を介して、図 8 の左側の【ダンパー(1)、ダンパー(4)、左㸚じ】と【ダンパー(2)、ダン パー(3)、右ねじ】が直列に接続されることから、以下の荷重の式(1)、 式(2)が成り立つ。ここで、慣性力は十分小さいことから無視した。

$$
\begin{aligned}
& \mathrm{S} 1+\mathrm{S} 4+\mathrm{L} 1=\mathrm{S} 2+\mathrm{S} 3+\mathrm{L} 2 \\
& (\mathrm{~S} 1+\mathrm{S} 4)-(\mathrm{S} 2+\mathrm{S} 3)=\mathrm{L} 2-\mathrm{L} 1
\end{aligned}
$$

図 12(b)よりダンパーの差分とねじの差分がほぼ一致し、式(2)が成 立寸ることがわかり、大振幅オイルダンパーシステムの荷重の流れ が想定通りであることが確認できる。図 13 には、振幅 $1150 \mathrm{~mm}$ 、速 
度 $100 \mathrm{~cm} / \mathrm{s}$ の加力で得られた大振幅オイルダンパーシステムの荷重変位関係を示す。図 13 より、大振幅オイルダンパーシステムの変 位が、既製のオイルダンパーの限界変位である $1000 \mathrm{~mm}$ を超えた変 位を記録していることが分かる。図 14 には変位調整機構を外した 状態で、定常波 10 波の正弦波加力した場合の全ダンパーの変位波 形を示す。図 14 より、変位調整機構がないと徐々にダンパーの変 位にドリフトが増大していくことから、変位調整機構が各ダンパー の変位を揃えるのに不可欠であることが分かる。

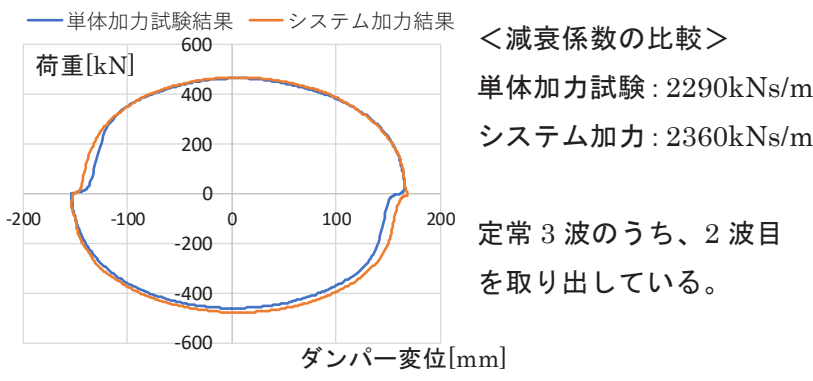

図 10 単体加力試験との比較（5秒_加力振幅 $320 \mathrm{~mm}$ )
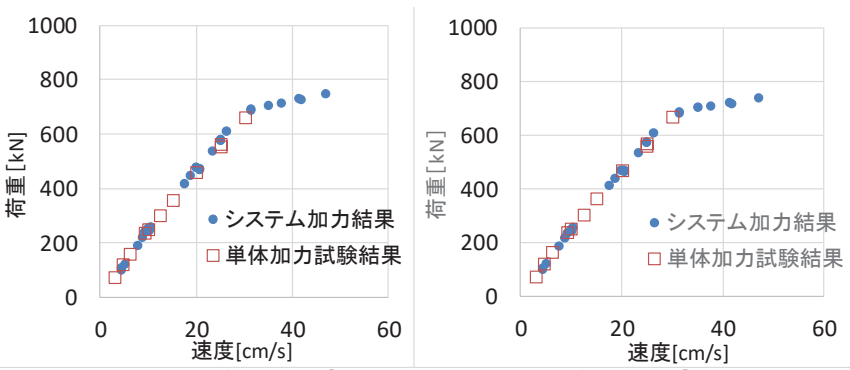

(a) ダンパー1

(b) ダンパー2)

図 11 全加力の最大荷重と最大速度の関係

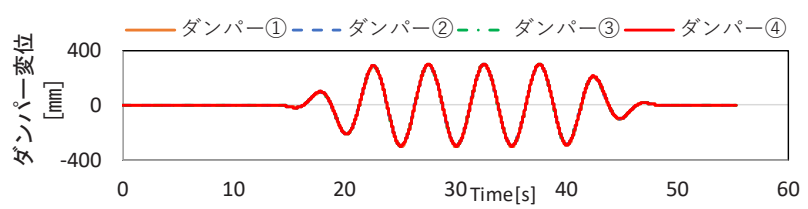

(a) 全ダンパーの変位波形

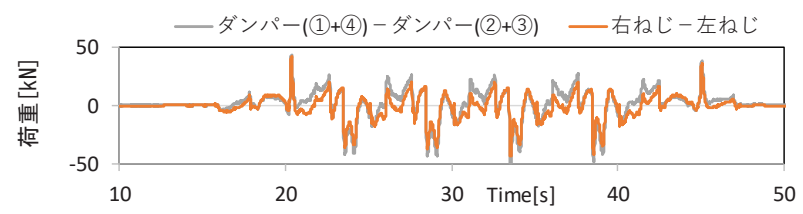

(b) 変位調整機構の荷重

図 12 時刻歴波形 (5 秒_加力振幅 $600 \mathrm{~mm}$ )

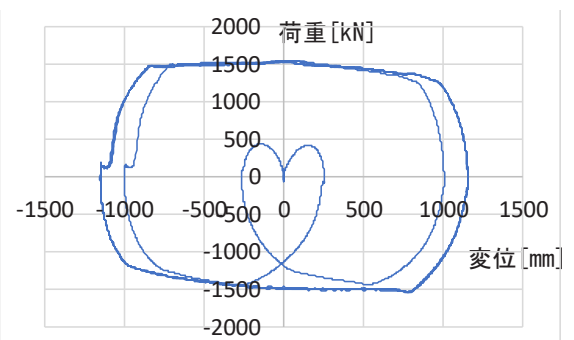

図 13 全体の荷重-変位関係（加力振幅 $1150 \mathrm{~mm}$ )

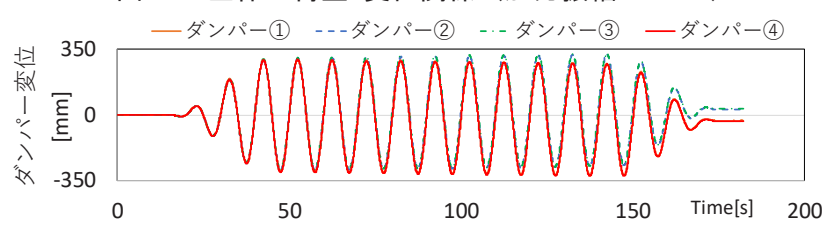

図 14 変位調整機構なしの全ダンパー変位波形

\section{4. 実大試験体の水平 2 方向動的試験}

\section{1 水平 2 方向試験体}

3 章では、ダンパー軸方向のみに変形する 1 方向試験体による加 力試験について示したが、地震時の免震建物の挙動に対応するため には水平 2 方向（X 方向 $\mathrm{Y}$ 方向）に稼働する必要がある。水平 2 方 向に対応させるため、図 8 に示寸 1 方向試験体の鉄骨架台下に、ク ロスリニアベアリングのような 2 方向に対応可能な支持材を設置し てダンパー直交方向に変位させた場合、ダンパー間の距離(例えばダ ンパー(1)とダンパー(2)の距離)が縮まり、鉄骨架台とダンパーが衝突 してしまう。あるいは、鉄骨架台下に転がり支承を設置し、架台自体 も建物の変位に対応して回転する機構とした場合、ダンパー(1)とダ ンパー(4)の変形量が揃わず、ダンパー性能に差が生じてしまう。すな わち、大振幅オイルダンパーシステムに設置されるダンパー群は、水 平 2 方向変位時に剛体的な挙動をする必要がある。

上記に示す課題に対処した上で水平 2 方向の稼働を可能にするた め図 15〜図 18 に示寸構成を考案した。ダンパーは横 1 列に配置す るのではなく、上下 2 本、左右 2 本と配置し、中央に変位調整機構 を通す。鉄骨架台は、鉄骨架台 1 と鉄骨架台 2 に分かれ、左右 2 本 (1)と (2)) のダンパーが接続される鉄骨架台 1 の左端には、全体荷 重 $(2000 \mathrm{kN})$ に対応可能なクレビスを設置する。上下 2 本のダンパー と右称じは先端のクレビスの穴位置が一致するように設置すること で、両端のクレビス間（図 15 の破線部）は剛体的に挙動する。ダン パー(3)とダンパー(4)はシリンダー部を鉄骨架台 2 に拘束することで、 3 ピン構造となるのを回避している。また鉄骨架台 1 と鉄骨架台 2 は、図 17 に示すようにリニアガイドで軸方向に変位自在に接続され る。 2 章で示したが、ダンパーには最大で $\pm 15 \%$ 減衰力の公差があ り、それから発生するモーメントをリニアガイドにより処理してい る。鉄骨架台は、転がり支承によって自重を支持する。2 方向試験体 の性能は、図 5 に示寸数值と同じである。水平 2 方向対応とするこ とでダンパーの全長は $5720 \mathrm{~mm}$ となる。

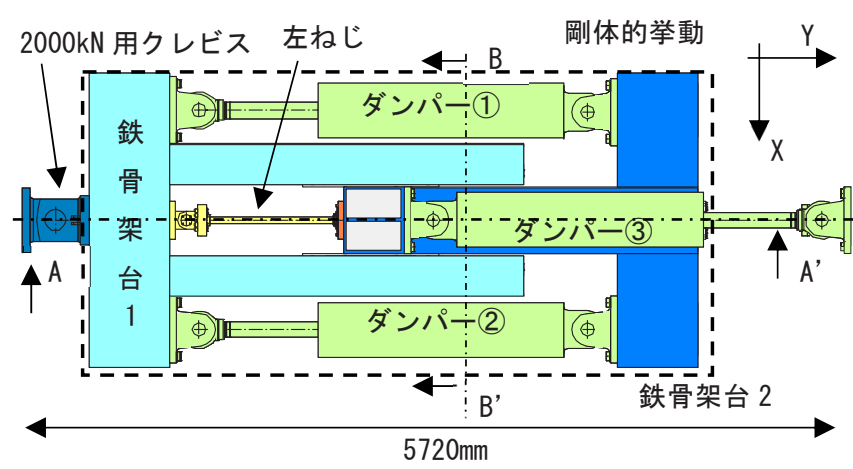

図 152 方向試験体平面図

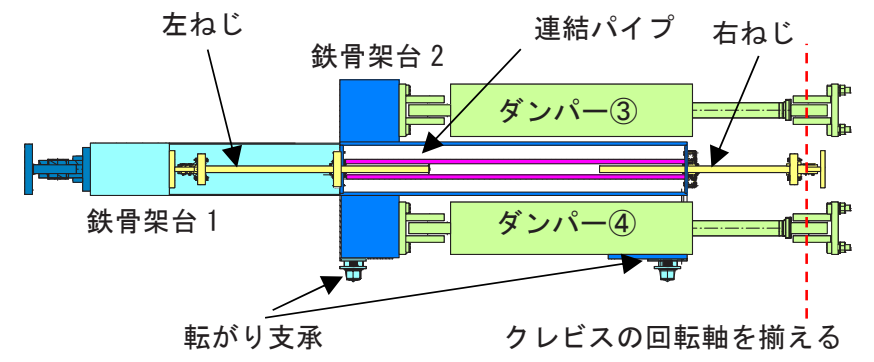

図 162 方向試験体 $\mathrm{A}^{-\mathrm{A}^{\prime}}$ 断面図 


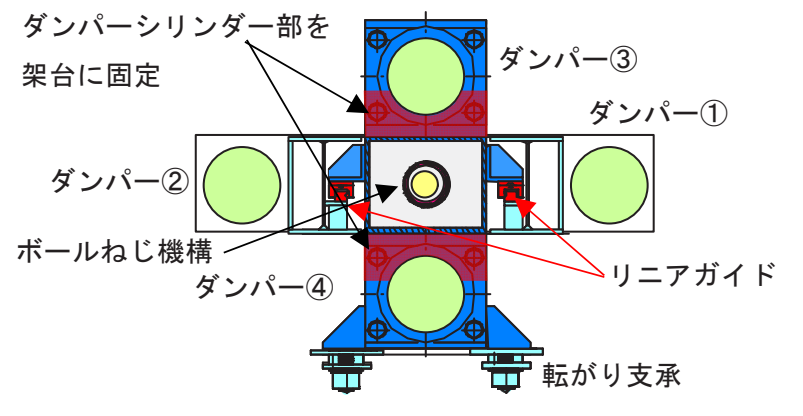

図 172 方向試験体 B-B' 断面図

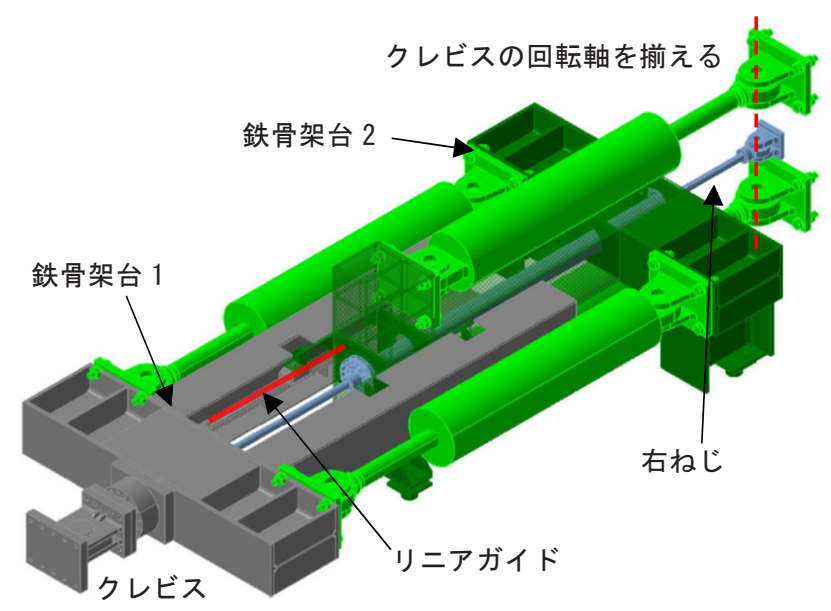

図 182 方向試験体アイソメ図

\section{2 水平 2 方向動的加力試験}

前節に示寸機構によって、大振幅オイルダンパーシステムが水平 2 方向変位に対して、1 方向試験体と同様の機構が成立し、想定通りの 性能を発揮することを確認するため、水平 2 方向動的加力試験を実 施した。2 方向加力試験は、写真 2 に示寸 3 軸加振振動台を加力機之 して用い、試験体の片端を固定端に接続し、水平 2 方向 $(\mathrm{X}$ 方向, $\mathrm{Y}$ 方向）の加力を行った。振動台の加力性能は、1 方向加力では最大 $\pm 800 \mathrm{~mm}$ であるが、 2 方向の円加力では、最大 $\pm 400 \mathrm{~mm}$ が限界変位 となる。なお、ダンパー軸方向を $\mathrm{Y} 、$ ダンパー直交方向を $\mathrm{X}$ とする。

\section{2.1 計測}

計測に使用する機器と設置位置を図 19 に示す。 1 方向加力試験と 同様に、 4 本の各ダンパー変位をレーザー変位計で計測し、荷重を各 ダンパーのピストンロッド部に貼り付けたひずみゲージで計測した。 さらに振動台の変位と荷重を、振動台に既設の変位計とロードセル を使用して計測した。2 方向試験体の全体荷重は、左端クレビスと鉄 骨架台 1 の間に設置した $1000 \mathrm{kN}$ 用のロードセルにより計測した。 2 方向試験体も図 5 に示寸ように、最大で $2000 \mathrm{kN}$ の荷重となるた め、 $1000 \mathrm{kN}$ を超える加力の際には、ロードセルを外して加力を行っ た。なお、本試験ではボールねじの荷重は計測していない。

\section{2.2 加力波}

加力波は、正弦波と地震応答解析から得られる免震層の応答波形 を用いた。正弦波は周期 3 秒 10 秒とし、変位振幅は最大で 1 方向 $\pm 600 \mathrm{~mm} 、 2$ 方向円加力で $\pm 400 \mathrm{~mm}$ 、加力速度は最大 $90 \mathrm{~cm} / \mathrm{s}$ の範囲 で加力した。正弦波の振幅は最大振幅となる部分を 3 波分 (定常部) とし、始めと終わりを 4 波ずつ漸増、漸減となるように作成した。地 震応答波は、30 階建ての $\mathrm{S}$ 造事務所建物（周期 7 秒）を想定した質
点モデルに 2007 年新潟県中越沖地震における柏崎(NIG018 柏崎)に て観測された波形を入力した際の免震層の応答変位波形を用いる。 図 20(a),(b)に想定建物モデルの免震層の時刻歴応答变位波形を示す。 なお、変位の大きい $\mathrm{NS}$ 波をダンパー軸方向(Y 方向)へ入力した。

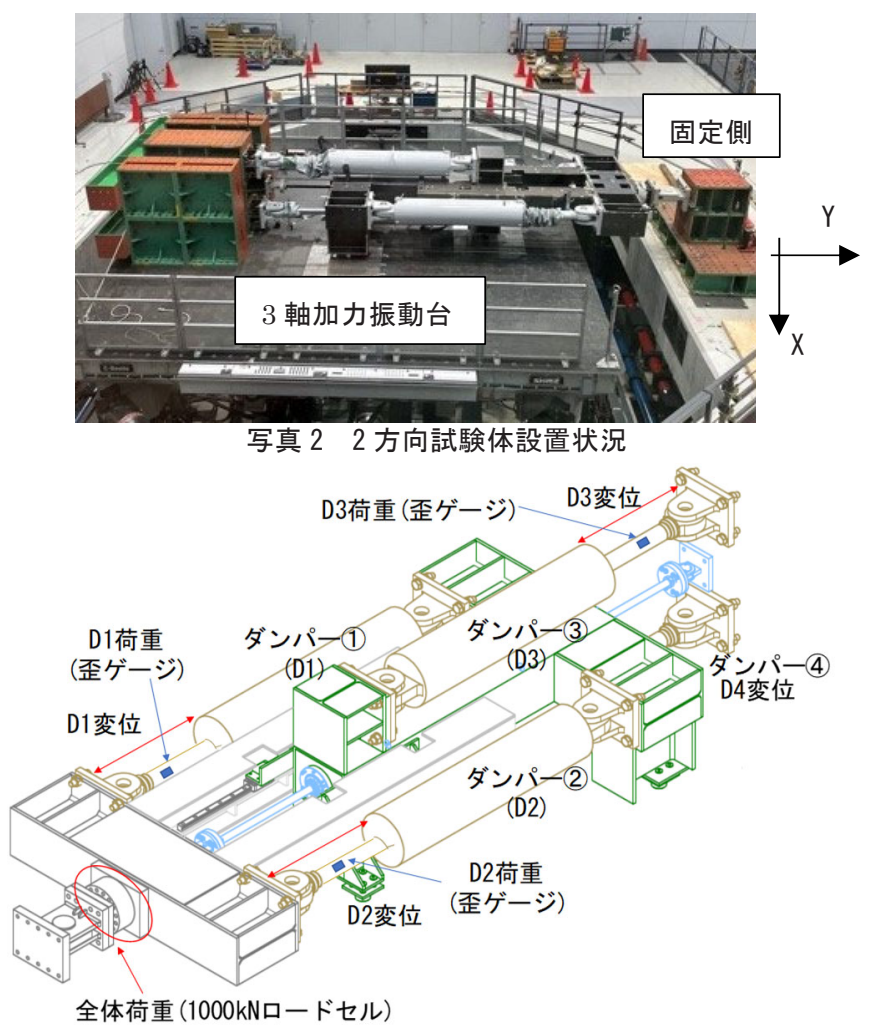

図 19 計測器設置位置

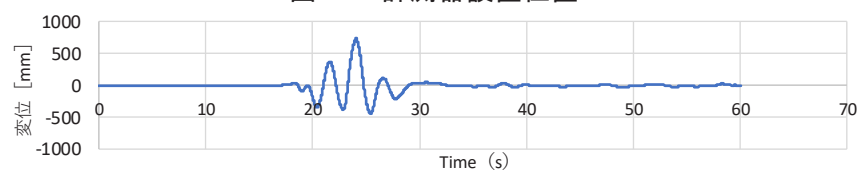

(a) NS 応答波 (Y 方向入力)

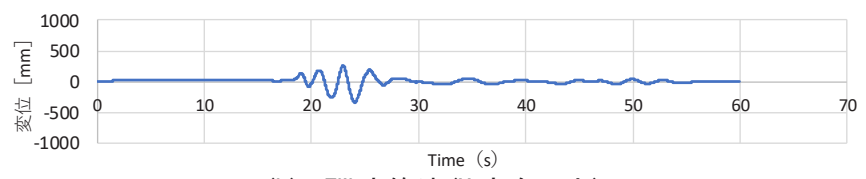

(b) EW 応答波 (X 方向入力)

図 20 新潟県中越沖地震柏崎の免震層応答変位波形

\section{3 試験結果}

2 方向試験体の荷重の流れも、式(1)、(2) と同様であるが、本試験 体では鉄骨架台下に転がり支承を使用しているため、摩擦抵抗力も 考慮する必要がある。動的加力試験に先立ち、試験体を準静的に引張 り、摩擦抵抗力を測定したところ、10kN であった。よって、本試験 体では、式(3)が成り立つ。

D1 荷重+D2 荷重+左ねじ荷重十摩擦抵抗力 $(10 \mathrm{kN})$

$=\mathrm{D} 3$ 荷重+D4 荷重+右永じ荷重+摩擦抵抗力 $(10 \mathrm{kN})$

$$
=\text { 全体荷重 }(1000 \mathrm{kN} \text { ロードセル) }
$$

図 21(a) (d)に加力周期 10 秒、加力振幅 $500 \mathrm{~mm}$ の 1 方向正弦波 加力結果を示寸。図 21(a)、(b)は、各ダンパーの変位波形と荷重波形 をそれぞれ重齐描いて示している。図21(a)より、全てのダンパー変 位が揃っており、水平 2 方向試験体も設計通り変位調整機構が機能 
したことが分かる。図 21(b)より、本試験結果では全てのダンパー荷 重が揃っている。図 21(c)に、D1 と D3 の変位和、D2 と D4 の変位 和、振動台変位を重衫描いて示す。図 21(c)上り、2 台の直列する夕゙ ンパー変位の和が振動台変位と一致しており、試験体が想定通りの 挙動をしたことがわかる。図 21(d)には、全体荷重と、D1+D2 の荷 重+摩擦抵抗力、D3+D4の荷重十摩擦抵抗力を重社描いている。直列 寸るダンパー荷重の差分がねじの荷重となるが、図 21(b)に示したよ うに、本試験で使用したダンパー性能には、ほとんど差異が無かった ため、ボールねじの荷重を入れなくても波形が揃う結果となった。

図 $22(\mathrm{a}) \sim(\mathrm{f})$ に地震応答波を水平 2 方向に入力した際の試験結果を 示す。地震応答波による加力は、 $1000 \mathrm{kN}$ 以上のダンパー荷重となる 大きい加力であるため、全体荷重を測定するロードセルを撤去して いる。そのため、各ダンパーの荷重はひずみゲージからの計測值で示 す。図 22(a)には、全ダンパーの変位波形を、図 22(b)には、並列す る 2 台のダンパー荷重和と摩擦抵抗力の和の波形を示寸。水平 2 方 向の地震応答波の加力についても、 1 方向正弦波加力と同様に全ダン パー変位が一致し、また並列する 2 台のダンパー荷重和も一致する。 さらに図 22(c)〜(f)に示す各ダンパーの荷重 - 変位関係も一致するこ とから、大振幅オイルダンパーシステムが水平 2 方向にも想定通り に挙動したことが確認できた。水平 2 方向正弦波による円加力の結 果についても同様の結果を得ている。

以上の試験結果より、水平 2 方向試験体が、水平 1 方向試験体と 同様の機構が成立し、水平 2 方向挙動時にも想定通りの性能を発揮 できることが確認できた。

\section{5.まとめ}

既製のオイルダンパーを用いて、大振幅かつ高速度に対応可能な 新たな大振幅オイルダンパーシステムを開発した。この実大試験体 を用いて、水平 1 方向 (最大 $115 \mathrm{~cm} / \mathrm{s}$ ) 及び水平 2 方向 (最大 $90 \mathrm{~cm} / \mathrm{s}$ ) の加力試験を実施し、システムの成立性確認と性能検証を行った。試 験結果より、本ダンパーシステムの変位調整機構を用いて直列接続 した各ダンパーの変位が揃うこと、全体荷重はダンパー単体荷重か ら計算される值となることが確認された。各ダンパー単体について は許容限界まで性能確認されていることから、この大振幅オイルダ ンパーシステムによれば既製オイルダンパーの 2 倍のストロークと 許容速度が確保できると考えられる。

\section{謝辞}

本論文で示した加力試験では、防災科学技術研究所の K-NET のデ ータを使用させて頂きました。ここに感謝の意を表します。

\section{参考文献}

1）建築研究所：長周期・長時間地震動の予測のためのデジタルデータの公開 （2014 年 11 月 25 日予定）について, 資料 1 ,

http://www.kenken.go.jp/japanese/information/information/press/2014/2 _1.pdf, 2014 (2017.3.6 参照)

2) 日本建築学会構造委員会・振動運営委員会 : シンポジウム東日本大震災か ら5 年 - 建築振動工学の到達点と残された課題 - , 2016

3) 福喜多輝ほか 5 名: 可変型オイルダンパーの開発その 1 , その 2 , 日本建築 学会大会学術講演梗概集, 構造II, pp.991 994, 2017.9

4) 田中鉄也ほか 7 名:巨大地震に対する免震建物のフェールセーフ機構その 1 , その 2 , 日本建築学会大会学術講演梗概集, 構造II, pp. $555 \sim 558,2014.9$

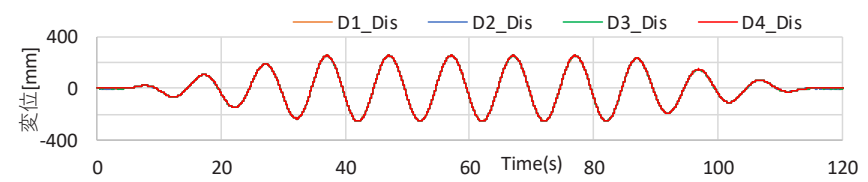

(a) 全ダンパー変位波形

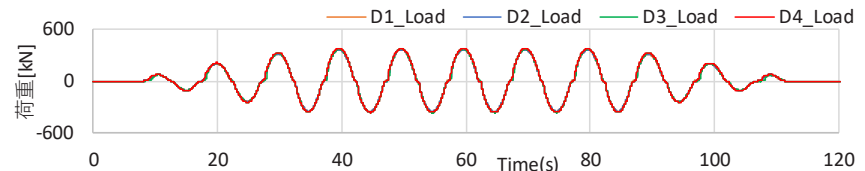

（b）全ダンパー荷重波形

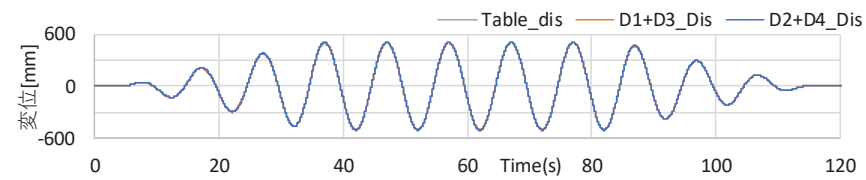

(c) 直列するダンパー変位和と振動台変位波形

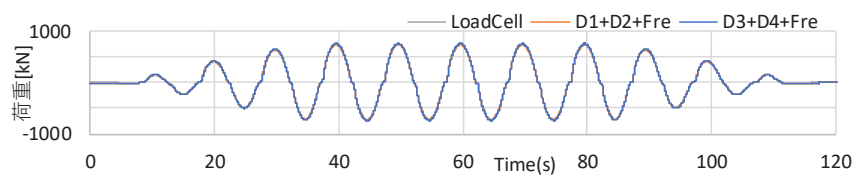

（d）並列するダンパー荷重和十摩擦抵抗力と全体荷重波形

図 21 加力結果（加力周期 10 秒、振幅 $500 \mathrm{~mm}$ 、速度 $31.4 \mathrm{~cm} / \mathrm{s}$ )

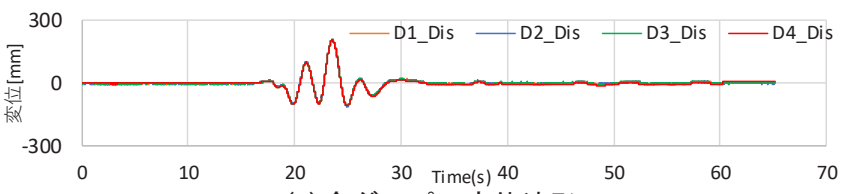

(a) 全ダンパー変位波形

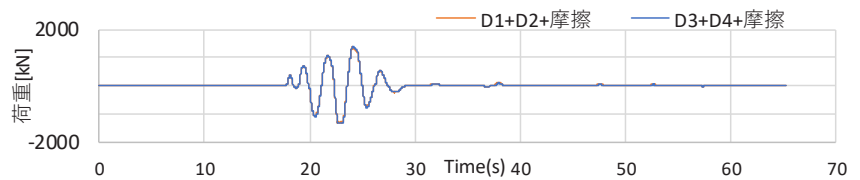

(b) 並列するダンパー荷重和十摩擦抵抗力の波形

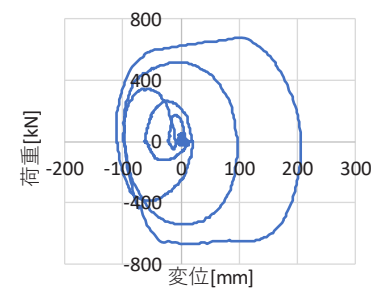

(c) D1 の荷重-変形関係

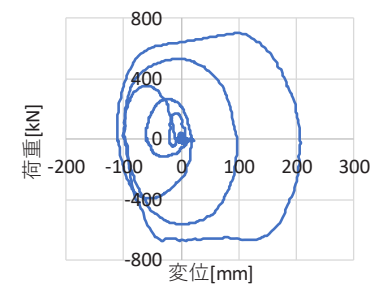

（e）D3 の荷重-変形関係
図 22 加力結果（新潟県中越沖地震柏崎 $60 \%$ 応答波）

5) 中山尚之ほか 6 名:免震効果と変位抑制を両立させた原子力建屋免震用才イ ルダンパの開発その 1 , その 2 , 日本建築学会大会学術講演梗概集, 構造II, pp.1133〜1136, 2019.9

6) 藤田聡ほか 5 名: 高速型免震用オイルダンパーの研究開発，日本建築学会大 会学術講演梗概集その 1 ，その 2 ，その 3 ，構造II，pp.727～732, 2020.9

[2021 年 1 月 29 日原稿受理 2021 年 3 月 30 日採用決定］ 